\title{
Agriculture and climate change: Potential for mitigation in Spain
}

Article in Science of The Total Environment · March 2017

DOI: 10.1016/j.scitotenv.2017.03.110

CITATIONS

0

4 authors, including:

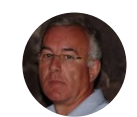

\section{Jose Albiac}

Centro de Investigación y Tecnología Agroali...

65 PUBLICATIONS 406 CITATIONS

SEE PROFILE

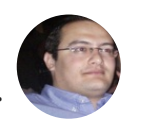

\section{Mohamed Taher Kahil}

International Institute for Applied Systems A...

26 PUBLICATIONS 72 CITATIONS

SEE PROFILE

\section{Eduardo Notivol}

Centro de Investigación y Tecnología Agroali...

46 PUBLICATIONS 500 CITATIONS

SEE PROFILE

Some of the authors of this publication are also working on these related projects: 


\title{
Agriculture and climate change: potential for mitigation in Spain
}

\author{
Jose Albiac ${ }^{a}$, Taher Kahil $^{b}$, Eduardo Notivol $^{\mathrm{c}}$, Elena Calvo ${ }^{\mathrm{d}}$ \\ a Department of Agricultural Economics, CITA \& IA2, Av. Montañana 930, 50059 Saragossa, Spain \\ ${ }^{b}$ International Institute for Applied Systems Analysis (IIASA), Schlossplatz 1, A-2361 Laxenburg, Austria \\ c Department of Forest Resources, CITA \& IA2, Av. Montañana 930, 50059 Saragossa, Spain \\ ${ }^{\mathrm{d}}$ Department of Economic Analysis, University of Zaragoza \& IA2, Gran Vía 2, Saragossa, Spain \\ Corresponding author: Jose Albiac \\ Address: Unidad Economia, CITA, Av. Montañana 930, 50059 Saragossa, Spain. \\ Tel: +34976716351; Fax: +34976716335. \\ emails: maella@unizar.es (J. Albiac); mt.kahil@gmail.com (T. Kahil); enotivol@aragon.es (E. Notivol); \\ ecalvo@unizar.es (E. Calvo)
}

\begin{abstract}
Agriculture and forestry activities are one of the many sources of greenhouse gas (GHG) emissions, but they are also sources of low-cost opportunities to mitigate these emissions compared to other economic sectors. This paper provides a first estimate of the potential for mitigation in the whole Spanish agriculture. A set of mitigation measures are selected for their cost-effectiveness and abatement potential and an efficient mix of these measures is identified with reference to a social cost of carbon of $40 € / \mathrm{tCO}_{2} \mathrm{e}$. This mix of measures includes adjusting crop fertilization and managing forests for carbon sequestration. Results indicate that by using the efficient mix of mitigation measures the annual abatement potential could reach 10 million $\mathrm{tCO}_{2} \mathrm{e}$, which represents $28 \%$ of current agricultural emissions in Spain. This potential could further increase if the social cost of carbon rises covering the costs of applying manure to crops. Results indicate also that economic instruments such as input and emission taxes could be only ancillary measures to address mitigation in agriculture. These findings can be used to support the mitigation efforts in Spain and guide policymakers in the design of country-level mitigation strategies.
\end{abstract}

Keywords. Climate change, Agriculture, Mitigation measures, Carbon sequestration, Abatement costs and benefits. 


\section{Introduction}

The increase in concentration of greenhouse gases (GHG) is largely driving the current and projected climate change in earth (IPCC, 2007). Anthropogenic global GHG emissions have been growing since pre-industrial times with a $90 \%$ increase between 1970 and 2011, driven by the use of fossil fuels, land use changes, and agriculture intensification (IPCC, 2014a). Estimates of global GHG emissions indicate a continuous rise over the next decades that would cause further warming and large changes in the global climate system (IPCC, 2014b). The agriculture and forestry sectors are responsible for about one fifth (about $10 \mathrm{GtCO}_{2} \mathrm{e} /$ year) of global anthropogenic GHG emissions. Agriculture releases about $12 \%$ of emissions, and it is the main source of non- $\mathrm{CO}_{2}$ emissions such as methane $\left(\mathrm{CH}_{4}\right)$ and nitrous oxide $\left(\mathrm{N}_{2} \mathrm{O}\right)$. Forestry releases 7\% of emissions (difference between sources and sinks) (Smith et al., 2014).

The only binding international agreement to reduce emissions under the United Nations Framework Convention on Climate Change (UNFCCC) is the Kyoto Protocol, which entered into force in 2005 and will end in 2020. The Kyoto Protocol does not include the three countries responsible for almost half of the GHG emissions: China, the USA and India. Also, several countries who signed the Kyoto Protocol have abandoned the agreement (Canada, Japan, New Zealand and Russia). However, a large number of countries have voluntarily pledged to reduce their emissions in the recent Paris Agreement (Richards et al., 2015). This agreement aims to hold the rise in global average temperatures by 2100 to well below $2^{\circ} \mathrm{C}$ above pre-industrial levels and to pursue efforts to limit the temperature increase to $1.5^{\circ} \mathrm{C}$.

Although the Paris agreement does not explicitly outline the role of agriculture in reducing global emissions, it makes clear that the global community must address the effects of climate change on agriculture to build resilience and enhance food security globally (UNFCCC, 2015). Several studies indicate that agricultural emissions will constitute the largest sector of surplus emissions in the future, as other sectors are projected to achieve large reductions by 2030, underlining the critical role of agriculture in meeting global climate targets (Bajzelj et al., 2014; Gernaat et al., 2015). Additionally, agriculture provides low cost alternatives to reduce GHG emissions 
compared to other sectors, which implies that excluding agricultural emissions from mitigation efforts will increase the cost of mitigation (Reisinger et al., 2013). Some attempts to quantify the global mitigation effort for agriculture by 2030 to stay within the $2^{\circ} \mathrm{C}$ limit using global agricultural and economic models indicate that it is about 1 $\mathrm{GtCO}_{2} \mathrm{e} /$ year, representing a $15 \%$ reduction over a business-as-usual scenario (Smith et al., 2014; Wollenberg et al., 2016). But these global estimates of agricultural mitigation potential are challenged under many local conditions, and the feasible mitigation potential at country level remains poorly understood (Grosso and Cavigelli, 2012).

Agricultural activities in Spain play an important role in the economy, but also generate significant GHG emissions to the atmosphere. However, there is a lack of a country-level strategy aimed at mitigating agricultural emissions (Alvaro-Fuentes et al., 2016). In recent years, many studies have examined the factors that control agricultural GHG emissions in a variety of regions in Spain evaluating the feasibility of a wide range of mitigation measures (Kahil and Albiac, 2012, 2013; Plaza-Bonilla et al., 2014; Sanchez et al., 2016). Despite the significant contributions of these studies, no study has yet provided information on the potential for mitigation in the whole Spanish agriculture, or integrated the results from different regions and fields of study.

The purpose of this paper is to provide a first estimate of the potential for mitigation in the agriculture and forestry sectors in Spain. This information could be useful to guide policymakers in the design of country-level mitigation strategies. The rest of the paper is organized as follows: section 2 gives an overview of the methodology and describes land use in Spain, the sources and sinks of GHG emissions in agriculture and forestry, and the mitigation measures to be analyzed. Section 3 presents the results, and section 4 concludes with the summary of findings and policy recommendations.

\section{Materials and methods}

Our approach to evaluate the potential for mitigation of agricultural GHG emissions in Spain follows three sequential steps. First, local and regional information on the costs and effectiveness of selected mitigation measures have been collected. Costs represent the impact on farmers' profits (the difference between gross benefits and 
production costs) or the increase in investment and operation costs from implementing each mitigation measure, and effectiveness measures the potential of each measure to abate GHG emissions. Subsequently, this information has been upscaled to country level by determining the extent of application of each measure in the different Spanish regions using data on land use and GHG emissions, and expert judgement. Second, the cost-effectiveness ratio of each mitigation measure (in $€$ per $\mathrm{tCO}_{2} \mathrm{e}$ abated) has been calculated and the measures have been ranked based on their cost-effectiveness using the Marginal Abatement Cost Curve (MACC) method, an assessment tool widely used in policy analysis (Moran et al., 2011).

Lastly, a cost-benefit analysis has been conducted using the results of the MACC and the social cost of the GHG emission damages estimated by OECD at $40 € / \mathrm{tCO}_{2} \mathrm{e}$ (Smith and Braathen, 2015). The cost-benefit analysis has been used to identify the efficient mix of measures that can potentially mitigate agricultural GHG emissions without damaging the social benefits generated by crop and livestock activities in Spain (Pearce et al., 2006; Perni and Martínez-Paz, 2013). However, the results of the cost-benefit analysis depend on the estimate of the social cost of carbon assumed in the empirical application. Thus, a sensitivity analysis has been conducted in order to assess the robustness of the results to different estimates of the social cost of carbon (20 and $80 € / \mathrm{tCO}_{2} \mathrm{e}$ ).

The main sources of information used in the calculations are the outcomes of various regional agro-economic models developed by the authors of the present paper during the last several years (Albiac et al., 2003; Kahil and Albiac, 2012 and 2013; Kahil et al., 2015a and 2015b; Kahil et al., 2016a, 2016b and 2016c; Martínez and Albiac, 2004 and 2006). These models integrate detailed biophysical and economic information of both the crop and livestock activities in various Spanish regions. Farmers' behavior is simulated under a wide range of environmental and policy scenarios, and provide information on economic benefits, inputs use, emission loads and activity level. Moreover, additional information on emissions and mitigation measures not covered by those models have been collected by reviewing the literature (Albiac et al., 2016; Daudén and Quílez, 2004; MAGRAMA, 2014, 2015a, 2015b, 2015c 
Table 1. Main field crops and fruit trees in dry and irrigated lands (1,000 ha).

\begin{tabular}{|lrc|}
\hline & Dryland & Irrigated Land \\
\hline Field crops & & \\
Barley & 2,600 & 230 \\
Wheat & 2,040 & 240 \\
Sunflower & 720 & \\
Corn & & 400 \\
Alfalfa & & 170 \\
Tomato & 55 \\
Lettuce & & 34 \\
\hline Fruit trees & & \\
Olive & 1,860 & 750 \\
Vineyard & 600 & 370 \\
Almond & 530 & \\
Orange & & 140 \\
Mandarine & & 100 \\
Peach & & 80 \\
\hline Total crops & 10,500 & 3,600 \\
\hline
\end{tabular}

and 2016; Montero et al., 2005; Notivol, 2008, 2009 and 2010; Orus et al., 2011; Teresa et al., 2016).

\subsection{GHG emissions from agriculture and carbon capture by forests}

Spain is located in the Iberian Peninsula in south-western Europe, covering an area of $506,000 \mathrm{~km}^{2}$. Most land in Spain is used in agricultural and forestry activities, which represent $72 \%$ of the land area. Another $19 \%$ is covered by meadows and pasture, and around 3\% is under urban and industrial land uses. Agricultural land use in Spain is dominated by rainfed cultivation that extends over 10.5 million ha. The main rainfed cultivated crops are barley, wheat and sunflower among field crops, and olive, vineyard and almond among fruit trees. Irrigated land amounts to 3.6 million ha, and the main cultivated crops are corn, wheat, barley, alfalfa, tomato and lettuce among field crops, and olive, vineyard, orange, mandarin and peach among fruit trees (Table 1) (MAGRAMA, 2015a, 2015b).

The prevailing irrigation technology in Spain is drip irrigation $(1,790,000$ ha), followed by surface irrigation $(980,000 \mathrm{ha})$ and sprinkle $(870,000 \mathrm{ha})$. In the last fifteen years, the area of surface irrigation has decreased by $30 \%$, while the area under drip and sprinkle irrigation technologies has increased by 70 and $15 \%$, respectively 
Table 2. Main livestock herds by region (1,000 heads).

\begin{tabular}{|lrrc|}
\hline & Swine & Cattle & Sheep \\
\hline Cataluña & 7,500 & & \\
Aragon & 6,300 & & \\
Castilla-Leon & & 1,300 & 3,100 \\
$\begin{array}{l}\text { Galicia } \\
\text { Extremadura }\end{array}$ & 900 & \\
\hline \multicolumn{1}{l}{ Spain } & & & 3,000 \\
\hline
\end{tabular}

(MAGRAMA, 2015c). Expansion of advanced irrigation systems is explained by the growing water scarcity problems, new investments in irrigation, and changes in cropping patterns. Traditional winter cereals have been substituted by more intensive summer crops, such as corn and alfalfa, and fruit trees such as vineyard and peach. Vegetables and fruits production is linked to important agrifood industries with a good quality and a strong export market.

Livestock production activities have significant social, economic and environmental importance. Spain has a large and capitalized swine production industry, with the swine herd exceeding 26 million heads, concentrated mainly in the regions of Cataluña and Aragon. The cattle herd reaches 6 million heads and it is located mainly in the regions of Castilla-Leon and Galicia. The sheep herd is close to 15 million heads located mainly in Castilla-Leon and Extremadura (Table 2) (MAGRAMA, 2015a).

During recent decades, the agricultural production in Spain became highly intensive in capital and technologies. This intensification is linked to high levels of fertilizers and agrochemicals use in cultivation to maximize crop yields, and a significant increase in livestock production mainly related to a rise in the proportion of animal protein in the diet of the Spanish population. The drawbacks from agriculture intensification are the overuse and mismanagement of mineral fertilizers and livestock manure, which are the main cause of $\mathrm{N}_{2} \mathrm{O}$ emissions, eutrophication of water courses, and atmosphere acidification. Figure 1 shows the density of nitrogen inputs in soils in Spain compared to other European Union regions.

In Spain, the application of mineral fertilizers and livestock manure to crops is 840.000 and $310.000 \mathrm{tN}$, respectively. However, the nitrogen available in livestock 
Figure 1. Density of the nitrogen inputs in European soils $\left(\mathrm{kgN} / \mathrm{km}^{2}\right)$.

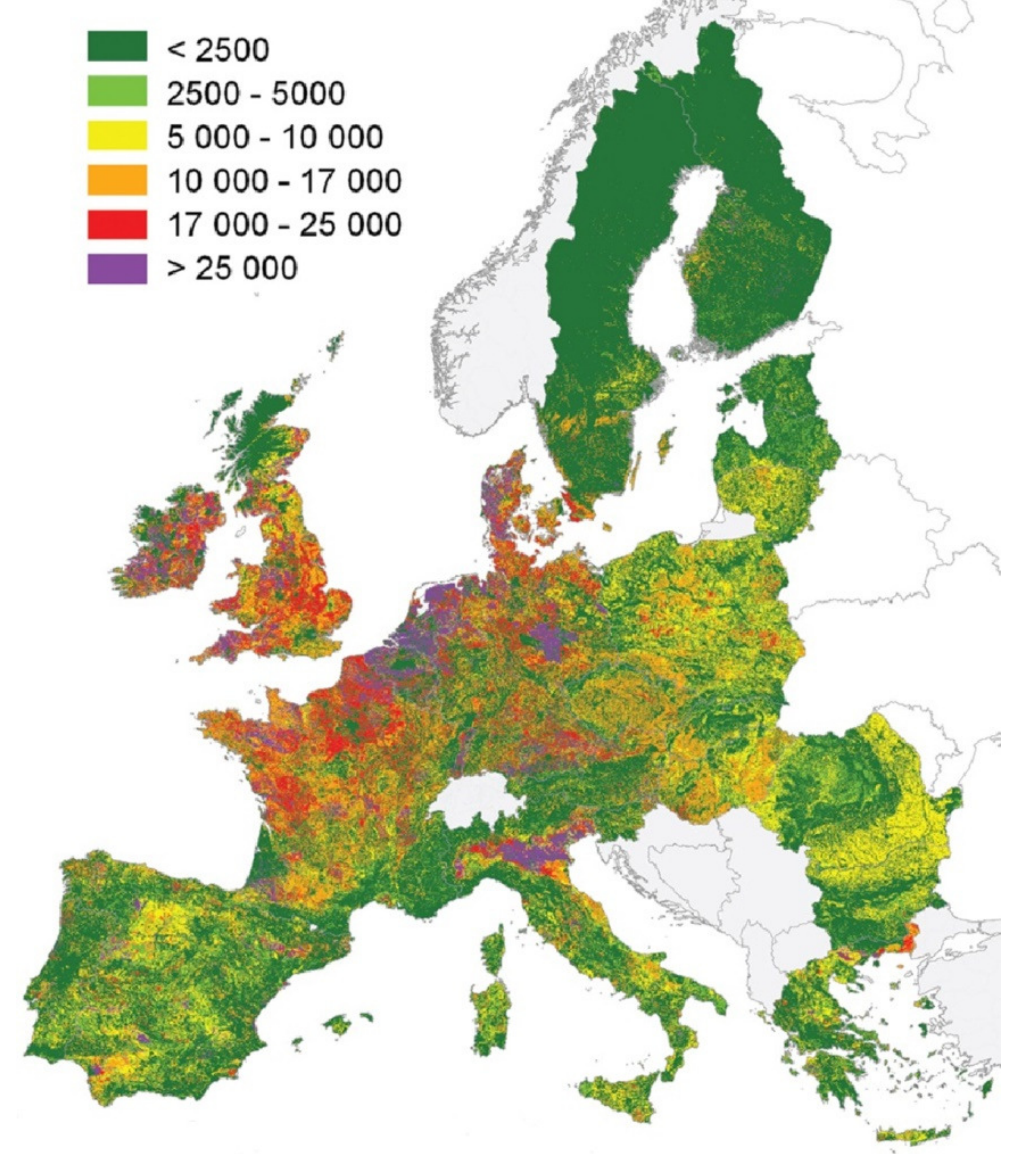

Source: Leip et al. (2011).

manure amounts to $710.000 \mathrm{tN}^{1}$ and therefore there are $400.000 \mathrm{tN}$ of remaining manure not used as fertilizer. This manure could be used to halve mineral fertilization. Also, total nitrogen fertilization should be reduced because current nitrogen fertilization from mineral and organic sources exceeds crop requirements by $33 \%$ $(380,000 \mathrm{tN}$ or $22 \mathrm{~kg} / \mathrm{ha})$ (MAGRAMA, 2014). This excessive nitrogen fertilization of crops and the remaining livestock manure not used as fertilizer add up to a surplus of $780.000 \mathrm{tN}$. This surplus is responsible for the large pollution loads that create serious environmental problems. These problems could be reduced by substituting synthetic fertilization for manure, and the benefits would be mitigating GHG emissions $\left(\mathrm{N}_{2} \mathrm{O}\right.$ and $\mathrm{CH}_{4}$ ), improving water quality (nitrogen in water courses), and reducing acidification (ammonia). However, empirical findings indicate that farmers in Spain do not take advantage of the large amount of manure available, because of the costs of

\footnotetext{
${ }^{1}$ Nitrogen in manure by herd is cattle $320.000 \mathrm{tN}$, swine $180.000 \mathrm{tN}$, sheep $100.000 \mathrm{tN}$, and fowl $100.000 \mathrm{tN}$.
} 
Table 3. GHG emissions from agriculture in Spain $\left(\mathrm{MtCO}_{2} \mathrm{e}\right)$.

\begin{tabular}{|lcc|}
\hline Type of GHG & $\mathrm{CH}_{4}$ & $\mathrm{~N}_{2} \mathrm{O}$ \\
\hline Total agricultural emissions & 19.5 & 16.0 \\
\hline Crops & & 13.7 \\
Direct emissions & & 10.4 \\
Indirect emissions & & 3.3 \\
\hline Livestock & 19.5 & 2.3 \\
Enteric fermentation & 11.7 & \\
Cattle & 7.5 & \\
Sheep & 3.0 & \\
Manure management & 7.8 & 2.3 \\
Swine & 5.7 & 0.5 \\
Cattle & 1.9 & 0.6 \\
Poultry & & 1.2 \\
\hline
\end{tabular}

transportation and spreading, the difficulties of management and the new equipment needed, and the uncertain results on crop yields (Orus et al., 2011).

At present, total GHG emissions in Spain amount to 329 million $\mathrm{tCO}_{2} \mathrm{e}$ (Hereafter $\mathrm{MtCO}_{2} \mathrm{e}$ ), which comply with the emission threshold allocated to Spain under the Kyoto protocol $\left(330 \mathrm{MtCO}_{2} \mathrm{e}\right)$, although further reductions have to be made under the European Union Climate and Energy Package in 2020, and the European Council Agreement in 2040. The main emitting sectors are transport (24\%), energy (23\%), and industrial (19\%) sectors, followed by agriculture (11\%). Emissions from the energy and industry sectors are regulated by the emission trading system, but the emissions from the diffuse sectors are not regulated and represent $60 \%$ of emissions (MAGRAMA, 2016). Agriculture releases $36 \mathrm{MtCO}_{2} \mathrm{e}$ of GHGs from crop and livestock activities. The costs of these emissions could be estimated at 1,440 million $€$, using the OECD carbon social cost of $40 € / \mathrm{tCO}_{2} \mathrm{e}$. These costs reduce the social welfare provided by agricultural activities, which generate 22,000 million $€$ in market profits.

Livestock emissions amount to $22 \mathrm{MtCO}_{2} \mathrm{e}$ of $\mathrm{CH}_{4}$ and $\mathrm{N}_{2} \mathrm{O}$. The main components are $\mathrm{CH}_{4}$ emissions from enteric fermentation $\left(12 \mathrm{MtCO}_{2} \mathrm{e}\right)$ of cattle and sheep, and manure management emissions $\left(10 \mathrm{MtCO}_{2} \mathrm{e}\right.$ ) of $\mathrm{CH}_{4}$ and $\mathrm{N}_{2} \mathrm{O} . \mathrm{CH}_{4}$ from manure is mostly generated by swine and cattle, while $\mathrm{N}_{2} \mathrm{O}$ from manure comes from poultry, cattle and swine (Table 3). The other major component of agricultural GHG emissions is $\mathrm{N}_{2} \mathrm{O}$ from crop fertilization, reaching close to $14 \mathrm{MtCO}_{2} \mathrm{e}$ in direct emissions from soils and indirect emissions from nitrogen leaching and runoff. As indicated above, 
Figure 2. Location of broadleaf and coniferous forests and carbon capture.

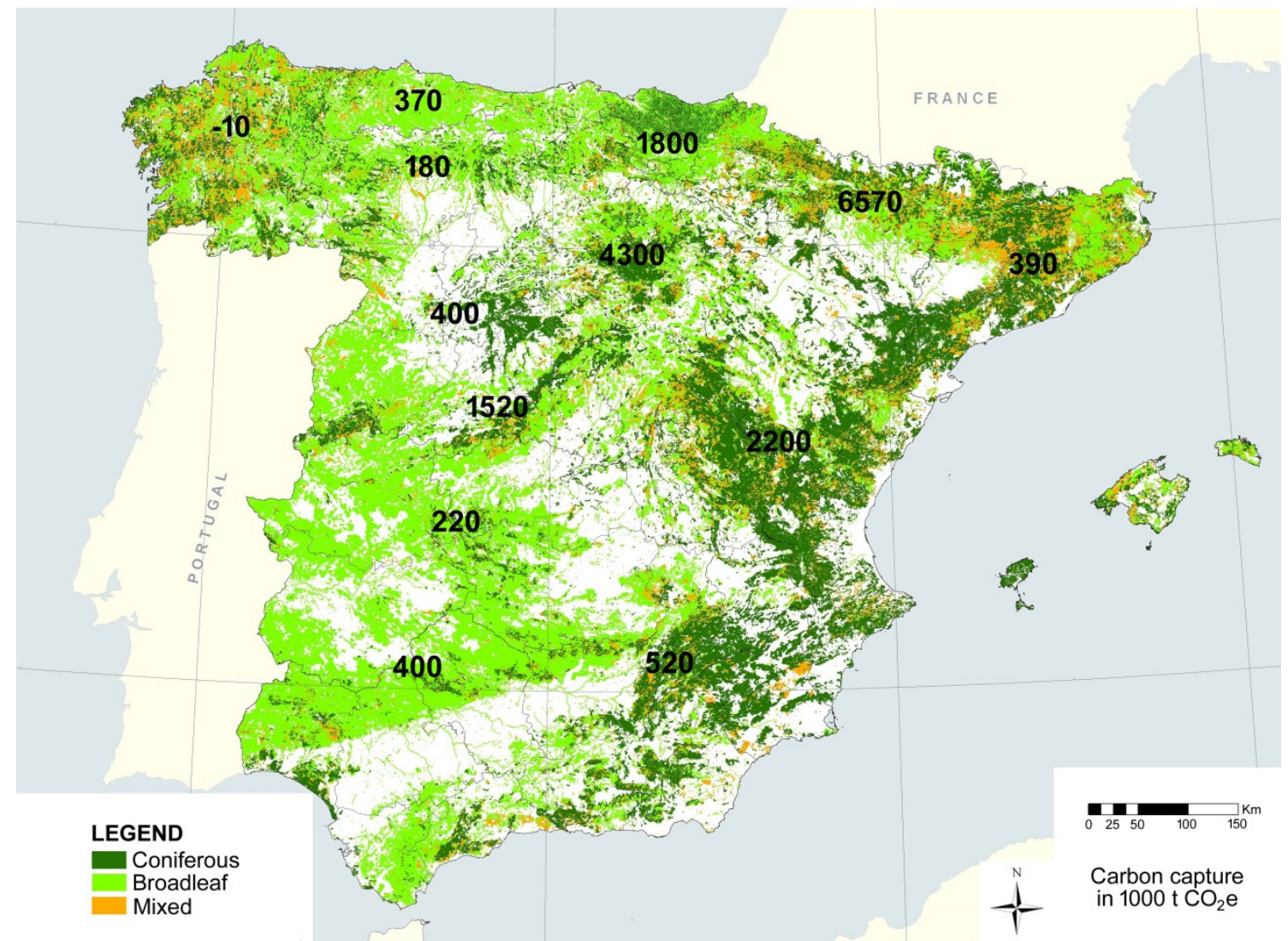

Sources: MARM (2008) and Bravo (2007). The figures of carbon capture correspond only to the main mountain ranges, but do not include all carbon sequestration.

mineral and organic fertilization of crops is excessive, with an amount of nitrogen fertilization from both mineral and organic sources close to 1.2 million $\mathrm{tN}$, which releases the direct and indirect $\mathrm{N}_{2} \mathrm{O}$ emissions. The main $\mathrm{N}_{2} \mathrm{O}$ emissions are coming from cereals (barley, wheat and corn), vegetables, citrus and olives (MAGRAMA, 2014).

Forests are important carbon sinks that offset the emissions from agriculture. The forested area in Spain extends over 18 million hectares, of which broadleaf forests cover $55 \%$ of the area, coniferous forests cover $37 \%$, and mixed forests cover $8 \%$ (Figure 2). The major forest species are Quercus ilex, Fagus sylvatica, Quercus pyrenaica, Quercus robur and Eucalyptus spp. among broadleaf forests, and Pinus pinaster, Pinus sylvestri, Pinus halepensis and Pinus nigra among coniferous forests. Public or collective property accounts for $45 \%$ of the forest land, and the remaining $55 \%$ is owned and managed by private smallholders. The carbon stock in Spanish forests exceeds $2,800 \mathrm{MtCO}_{2} \mathrm{e}$, and every year forests remove $35 \mathrm{MtCO}_{2} \mathrm{e}$ from the atmosphere (Montero et al., 2005). The environmental benefits from annual carbon 
sequestration can be estimated at 1,400 million $€$ per year using the OECD carbon social cost of $40 € / \mathrm{tCO}_{2} \mathrm{e}$, exceeding the current market value of forest production activities (800 million $€$ ).

There is a spatial concentration of GHG emissions in the middle Ebro, the lower Guadalquivir and the Duero basins because of the intensive irrigation and large livestock herds located in these regions. By contrast, the larger carbon sinks are located in areas with low agricultural income based on quite extensive production activities linked to forestry, such as Northwestern Spain, the Pyrenees and the Iberic mountain range (Figure 2).

\subsection{Evaluation of mitigation measures in agriculture and forestry}

A set of measures to abate GHG emissions from agriculture have been identified and evaluated in the literature including improvements in the management of cropland, livestock and forests, and the use of economic instruments. Land management measures include a more precise application of nitrogen fertilization, reducing tillage, using cover crops and crop rotations, and substituting synthetic fertilizers by organic fertilizers (Paustian et al., 2016). Livestock management measures include intensifying livestock production, abating emissions from manure, and reducing demand of livestock products. Specific measures for enteric fermentation are using feed additives, modifying the feed diet and improving feed digestibility. Measures for manure management are proper manure storage, application of manure to crops, and investments in manure treatment technologies using biological, physical and chemical processes (Herrero et al., 2016; Smith et al., 2007). Forest management measures have a large abatement potential by implementing a forest management oriented towards carbon capture, although there is a trade-off between water use and carbon capture in areas under severe water scarcity. Economic instruments include taxes levied on emissions or on inputs, subsidies to promote the adoption of low emissions farming technologies, and emission trading (De Cara et al., 2005; Pérez Domínguez et al., 2009).

In this paper, we focus on mitigation measures related to crop fertilization, manure in livestock, and carbon capture in forests. Measures for crop fertilization are 
standards on nitrogen fertilization, taxes levied on nitrogen fertilization and on irrigation water, taxes levied on $\mathrm{N}_{2} \mathrm{O}$ emissions from crops, and investments in efficient irrigation technologies. Measures for livestock are application of manure to crops and investments in manure treatment technologies. These treatment technologies are based on biological processes such as anaerobic digestion, nitrification/denitrification and composting, which have high investment and operating costs. Other treatment technologies are based on solid-liquid separation with lower costs depending on the scale of operation. In forestry, the measure is management regimes oriented to carbon sequestration which could be achieved by modifying the spacing, rotation age and thinning regime of forests stands. Table 4 provides a description of the selected mitigation measures and the sources of information. The abatement costs of crop and forest measures indicate the change in famers' profits per ton of abatement, while the abatement costs of livestock measures indicate the investment and operation costs per ton of abatement required to achieve such abatement.

Here, the choice of mitigation measures is based on the available information on cost-effectiveness and possible linkages with other environmental policies dealing with water and climate change adaptation. Also, some measures have already been implemented in some Spanish regions, such as manure treatment technologies or collective management of manure in crop fertilization, which may facilitate their transfer to other regions. It should be noted that many of the selected mitigation measures when applied in combination interact, and their abatement potential and cost-effectiveness would likely change in response to the combination. For example, if a tax on nitrogen fertilization is implemented, then less $\mathrm{N}$ fertilizer is used lessening the abatement potential of fertilization standards or manure fertilization. In this paper, the stand-alone values of the abatement cost and potential of each measure have been considered in the calculations and the interaction effects among measures have not been included because these effects remain largely unexplored in the literature. ${ }^{2}$

\footnotetext{
${ }^{2}$ This assumption do not affect the results obtained in this paper because the best policy mix presented in section 3 combines measures that do not interact. However, the interaction effect should be further investigated in future studies.
} 
Table 4. Mitigation measures in crop cultivation, livestock and forests.

\begin{tabular}{|c|c|c|}
\hline Measures & Description & References \\
\hline \multicolumn{3}{|c|}{ Crop measures } \\
\hline Fertilization standards & $\begin{array}{l}\text { Nitrogen fertilizer is applied at adequate rates supplying enough nitrogen to both dryland and } \\
\text { irrigated crops to meet expected yields based on recommendation of the extension services. }\end{array}$ & Kahil and Albiac, 2012, 2013 \\
\hline Emission tax & $\begin{array}{l}\text { Tax levied on both direct (from fertilization) and indirect (from leaching and runoff) } \mathrm{N}_{2} \mathrm{O} \\
\text { emissions. The tax rate is } 40 € / \mathrm{tCO}_{2} \mathrm{e} \text { equal to the } \mathrm{OECD} \text { carbon social cost. }\end{array}$ & Kahil and Albiac, 2012, 2013 \\
\hline Nitrogen tax & $\begin{array}{l}\text { A } 50 \% \text { increase of the current price of mineral nitrogen fertilizer. This increase is equal to } 0.5 \\
€ / \mathrm{kgN} \text {. }\end{array}$ & $\begin{array}{l}\text { Kahil and Albiac, 2012, 2013; } \\
\text { Martínez and Albiac, 2004; Martínez } \\
\text { and Albiac, } 2006\end{array}$ \\
\hline Water tax & A $50 \%$ increase of the current price of irrigation water. This increase is equal to 2.5 cent $€ / \mathrm{m}^{3}$. & $\begin{array}{l}\text { Kahil and Albiac, 2012, 2013; Kahil et } \\
\text { al., 2016c; Martínez and Albiac, 2004; } \\
\text { Martínez and Albiac, } 2006\end{array}$ \\
\hline $\begin{array}{l}\text { Irrigation } \\
\text { modernization }\end{array}$ & $\begin{array}{l}\text { Upgrading irrigation networks and replacing less-efficient surface irrigation system by more- } \\
\text { efficient sprinkler and drip systems. The cost of irrigation modernization is } 300 € / \text { ha. }\end{array}$ & $\begin{array}{l}\text { Kahil and Albiac, 2012; Kahil, 2011; } \\
\text { Lecina et al., } 2009\end{array}$ \\
\hline \multicolumn{3}{|c|}{ Livestock measures } \\
\hline $40 \%$ manure share & $\begin{array}{l}\text { Increasing the share of manure fertilization in total applied nitrogen from } 27 \text { to } 40 \% \text {. To } \\
\text { achieve this increase manure have to be transported up to } 5 \mathrm{~km} \text { with a cost of } 2.6 € / \mathrm{m}^{3} \text { of } \\
\text { manure. }\end{array}$ & $\begin{array}{l}\text { Albiac et al., 2016; Daudén et al., } \\
\text { 2011; Teresa et al., } 2016\end{array}$ \\
\hline $55 \%$ manure share & $\begin{array}{l}\text { Increasing the share of manure fertilization in total applied nitrogen from } 40 \text { to } 55 \% \text {. To } \\
\text { achieve this increase manure have to be transported up to } 15 \mathrm{~km} \text { with a cost of } 4.8 € / \mathrm{m}^{3} \text { of } \\
\text { manure. }\end{array}$ & $\begin{array}{l}\text { Albiac et al., 2016; Daudén et al., } \\
\text { 2011; Teresa et al., } 2016\end{array}$ \\
\hline $\begin{array}{l}\text { Manure treatment } \\
\text { plants }\end{array}$ & $\begin{array}{l}\text { Investing in manure treatment plants based on Nitrification/denitrification process, with a } \\
\text { treatment capacity of } 50,000 \mathrm{~m}^{3} \text { and a cost of } 7 € / \mathrm{m}^{3} \text { of manure. }\end{array}$ & $\begin{array}{l}\text { Albiac et al., 2016; Flotats et al., } \\
\text { 2011; Teresa et al., } 2016\end{array}$ \\
\hline \multicolumn{3}{|c|}{ Forest measures } \\
\hline Forest management & $\begin{array}{l}\text { Adopting a forest management regime oriented towards carbon sequestration. This can be } \\
\text { achieved by changing the spacing, rotation and thinning of stands. Costs do not increase. }\end{array}$ & $\begin{array}{l}\text { Kahil and Albiac, 2012; Notivol, 2008, } \\
\text { 2009, } 2010\end{array}$ \\
\hline
\end{tabular}


Figure 3. Marginal abatement cost curve.



Note. The cost-effectiveness and abatement potential of each measure represent stand-alone values and do not include the interaction effect among measures.

\section{Results}

Figure 3 shows the abatement cost and potential of the selected mitigation measures. Each of the bars in Figure 3 represents an individual mitigation measure. The vertical axis represents the abatement cost, where negative abatement cost values mean savings. The horizontal axis represents total abatement potential of each measure, with the bar width indicating the magnitude of the abatement potential.

Economic measures considered here are taxes levied on $\mathrm{N}_{2} \mathrm{O}$ emissions from cultivation, and taxes on the inputs nitrogen fertilizer and irrigation water, aimed at internalizing the damages from GHG emissions, akin to a carbon tax for agriculture. Results show that the costs of these taxes are substantial for farmers, given by the losses in their private benefits. The costs of a tax on nitrogen fertilization or a tax on emissions of $\mathrm{N}_{2} \mathrm{O}$ are 310 and $230 € / \mathrm{tCO}_{2} \mathrm{e}$, respectively, both achieving an abatement of $18 \%$ in $\mathrm{N}_{2} \mathrm{O}$ emissions (2.5 $\mathrm{MtCO}_{2} \mathrm{e}$ ). A tax on irrigation water is too inefficient to be considered, because abatement is only $3 \%\left(0.4 \quad \mathrm{MtCO}_{2} \mathrm{e}\right)$ and costs are disproportionate at 2,170 $€ / \mathrm{tCO}_{2} \mathrm{e}$. 
Another measure considered is investing in advanced irrigation technologies. This is achieved through upgrading the distribution networks of irrigation districts, and replacing less-efficient surface irrigation system in parcels by more-efficient sprinkle and drip systems. The modernization costs of $300 € /$ ha indicated in table 4 are the annual amortization of the investments during the life cycle of the investments. Efficient irrigation systems require less nitrogen fertilizer application, generate less nitrogen leaching, and could increase crop yields compared to old systems. This measure can be applied to the current 1 million ha of surface irrigation in Spain. Results indicate that irrigation modernization would involve significant abatement costs at $400 € / \mathrm{tCO}_{2} \mathrm{e}$, with an abatement potential of $2.1 \mathrm{MtCO}_{2} \mathrm{e}(15 \%$ of emissions). It is important to note that the impact of irrigation modernization on energy use and the ensuing $\mathrm{CO}_{2}$ emissions is not included in this paper because of the lack of reliable information on the full energy and $\mathrm{CO}_{2}$ emission impacts of this measure.

A standard on nitrogen fertilization, which adjusts nitrogen application to crop uptake without reducing crop yield and area, is an interesting measure achieving a $21 \%$ abatement $\left(2.9 \mathrm{MtCO}_{2} \mathrm{e}\right)$ at negative costs of $-110 € / \mathrm{tCO}_{2} \mathrm{e}$. However, organizing the control and enforcement of this measure is quite challenging and will involve substantial transaction costs, such as measurement of nitrogen loads in return flows from irrigation districts. The approach of the European Nitrates Directive to deal with the enforcement of fertilization standards is to require a nitrogen balance book from farmers drawn randomly. Farms located in zones officially declared vulnerable to nitrate pollution but not complying with the fertilization standards are penalized in their CAP payments. Yet, the efficacy of the Nitrates Directive control mechanisms after two decades remains to be seen as the high pollution loads in figure 1 show. ${ }^{3}$ The reasons are that the Nitrate Directive ignores pollution loads and damages in whole basins, disregards any limits on synthetic fertilizers, overlooks polluting crops not

\footnotetext{
${ }^{3}$ The issue to be addressed in Europe is that livestock manure contains 7 million $\mathrm{tN}$, and this manure can substitute a considerable part of the 11 million $\mathrm{tN}$ contained in synthetic fertilizers. The nitrogen surplus results in 6 million $\mathrm{tN}$ of nitrogen inputs from agriculture into European aquatic systems (Leip et al. 2011), contributing with a major share to the 4 million tN of nitrogen river loads that pollute coastal waters (Seitzinger et al. 2010).
} 
receiving CAP subsidies such as vegetables and fruit trees, and also because the shaky enforcement mechanism is not linked to ambient pollution loads (Albiac, 2009).

Using manure to substitute synthetic fertilizers in crops is another interesting option for reducing the entry of nitrogen in soils and the ensuing $\mathrm{N}_{2} \mathrm{O}$ emissions, and also for preventing very costly investments in manure treatment technologies (Flotats et al., 2011). The measure is being already implemented in the Bardenas irrigation district in the Ebro basin through collective management without subsidies (Daudén et al. 2011). Manure application to fields is a good alternative for the Guadalquivir, middle Ebro, and Duero basins, where large irrigation districts are coupled with high livestock density areas. ${ }^{4}$

At present, manure provides $27 \%$ of nitrogen crop fertilization in Spain $(310,000$ $\mathrm{tN})$, and the measure considered here is to increase the share of manure up to $40 \%$ $(460.000 \mathrm{tN})$ and then to $55 \%(630.000 \mathrm{tN})$, while reducing synthetic fertilization. It is assumed that manure is transported 5 kilometers from livestock farms to crop fields to achieve the $40 \%$ share of manure, and is transported up to 15 kilometers to achieve the $55 \%$ share of manure. These are only potential shares of manure because organizing manure application to crops requires farmers' cooperation, with sizable transactions costs involved. The information is taken from the results of manure application experiments in the middle Ebro valley (Albiac et al., 2016; Daudén et al., 2011; Teresa et al., 2016). The costs of manure application include the load, transport, unload and spreading operations, and the use of specialized equipment (tractor, tank and applicator). The costs per cubic meter of manure are $2.6 €$ for a distance of 5 kilometers and $4.8 €$ for 15 kilometers. The $40 \%$ share of manure reduces synthetic nitrogen fertilization by $150.000 \mathrm{tN}$, abating direct and indirect $\mathrm{N}_{2} \mathrm{O}$ emissions by 1.26 $\mathrm{MtCO}_{2} \mathrm{e}$ at $75 € / \mathrm{tCO}_{2} \mathrm{e}$. The $55 \%$ share implies an additional reduction of $170.000 \mathrm{tN}$ in synthetic fertilization abating emissions by $1.43 \mathrm{MtCO}_{2} \mathrm{e}$ at $140 € / \mathrm{tCO}_{2} \mathrm{e}$.

Another measure considered here is the use of manure treatment technologies. These technologies require substantial investments and high operation and

\footnotetext{
${ }^{4}$ Irrigation area is 850.000 ha in Guadalquivir, 780,000 in Ebro and 550,000 in Duero. Swine density is high in the three basins, while cattle density is high in the Duero and Guadalquivir basins.
} 
maintenance costs. For example, a large plant for collective management of manure $\left(50,000 \mathrm{~m}^{3} /\right.$ year $)$ with a nitrification/denitrification process, requires an investment close to 1.5 million $€$ (Flotats et al., 2011). Thus, treatment plants could be built when there is no option of applying manure in crops to close the nitrogen loop between livestock and crop production. The costs of $\mathrm{N}_{2} \mathrm{O}$ abatement with manure treatment plants are around $200 € / \mathrm{tCO}_{2} \mathrm{e}$. The abatement of $\mathrm{N}_{2} \mathrm{O}$ with treatment plants could go up to $1.4 \mathrm{MtCO}_{2} \mathrm{e}$, which corresponds to treating all manure not used at present as fertilizer in Spain (400.000 tN).

Forest management oriented to maximize tree and soil carbon storage is another promising strategy to offset GHG emissions in Spain. Management for carbon capture could be achieved by modifying the spacing, rotation age and thinning regime of forests stands, taking into account the fire recurrence especially in Mediterranean forests. The comparison between the costs involved in current management operations and carbon capture management operations shows that carbon capture management regimes do not increase the current costs of forest management, and costs could even decrease in some cases. By applying the carbon capture regimes, the average increase in annual carbon sequestration is around 20\% (Notivol 2008, 2009 and 2010; Kahil and Albiac 2012), which would increase carbon capture by forests in Spain from the current 35 up to $42 \mathrm{MtCO}_{2} \mathrm{e} .^{5}$

Table 5 presents the results of the cost-benefit analysis. This analysis shows the mix of mitigation policy measures that can be used to abate agricultural GHG emissions without damaging the social benefits generated by the crop and livestock activities in Spain. Results indicate that nitrogen standards entail large environmental benefits from $\mathrm{N}_{2} \mathrm{O}$ abatement coupled with significant private benefits to farmers from savings in nitrogen fertilization. In monetary terms, the environmental benefits are 120 million $€$ and private costs are negative (-320 million $€$ ), so social benefits amount to 440 million $€$. As indicated above, a caveat on fertilization standards is the transaction costs involved in this measure, which are highlighted by the poor performance of two

\footnotetext{
${ }^{5}$ These calculations include carbon sequestration from study cases on important species in Spain: Pinus halepensis, Pinus sylvestris, Pinus nigra and Quercus pyrenaica.
} 
Table 5. Social benefits from GHG mitigation in agriculture.

\begin{tabular}{|lcccc|}
\hline \multicolumn{1}{|c}{ Measures } & $\begin{array}{c}\text { Abatement } \\
\text { potential } \\
\text { (MtCO }\end{array}$ & $\begin{array}{c}\text { Environmental } \\
\text { benefits } \\
\text { (M€) }\end{array}$ & $\begin{array}{c}\text { Private costs } \\
\text { (M€) }\end{array}$ & $\begin{array}{c}\text { Social } \\
\text { benefits } \\
\text { (M€) }\end{array}$ \\
\hline Fertilization standards & 2.9 & Crop measures & \\
Emission tax & 2.5 & 120 & -320 & 440 \\
Nitrogen tax & 2.5 & 100 & 570 & -470 \\
Irrigation modernization & 2.1 & 100 & 770 & -670 \\
Water tax & 0.4 & 80 & 810 & -730 \\
\hline \multicolumn{5}{c}{ Livestock measures } \\
40\% manure share & 1.3 & 50 & 870 & -850 \\
55\% manure share & 2.7 & 110 & 100 & -50 \\
Manure treatment plants & 1.4 & 60 & 300 & -190 \\
\hline \multicolumn{5}{c}{ Forest measures } \\
Forest management & 7.0 & 280 & -220 \\
\hline
\end{tabular}

Note: Environmental benefits are equal to the abatement potential times the OECD carbon social cost $\left(40 € / \mathrm{tCO}_{2} \mathrm{e}\right.$ ). Private costs are equal to the abatement potential times the abatement costs (from figure 1). Social benefits are equal to the difference between environmental benefits and private costs.

decades of the Nitrates Directive in the European Union (Figure 1). Both a tax on $\mathrm{N}_{2} \mathrm{O}$ emissions and a tax on the inputs nitrogen or irrigation water reduce social benefits because the private costs of abatement are above environmental benefits. Investments in irrigation modernization result also in negative social benefits due to the high private costs of investments. On the other hand, all livestock measures abate GHG emissions but the social benefits are negative because of the high private costs compared to environmental gains. In forestry, a change in forest management regime oriented towards carbon sequestration contributes with a large abatement and positive social benefits.

The results in table 5 indicate that the best policy mix to abate agricultural GHG emissions in Spain is combining fertilization standards with a carbon sequestration regime in forest management. These two measures maximize social benefits up to 720 million $€$ with no private costs but rather private benefits. The mitigation potential is close to $10 \mathrm{MtCO}_{2} \mathrm{e}\left(2.9 \mathrm{MtCO}_{2} \mathrm{e}\right.$ in agriculture and $7 \mathrm{MtCO}_{2} \mathrm{e}$ in forestry), representing $28 \%$ of current agricultural emissions. It should be noted that the environmental benefits from the crop, livestock and forest measures presented in table 5 include only the benefits from reducing GHG emissions. However, these mitigation measures 
Table 6. Sensitivity analysis of social benefits under different social costs of carbon.

\begin{tabular}{|c|c|c|c|}
\hline \multirow[t]{2}{*}{ Measures } & \multirow{2}{*}{$\begin{array}{l}\text { Abatement potential } \\
\qquad\left(\mathrm{MtCO}_{2} \mathrm{e}\right)\end{array}$} & \multicolumn{2}{|c|}{ Social benefits (M€) } \\
\hline & & $\begin{array}{l}\text { with social costs of } \\
\text { carbon at } 20 € / \mathrm{tCO}_{2} \mathrm{e}\end{array}$ & $\begin{array}{l}\text { with social costs of } \\
\text { carbon at } 80 € / \mathrm{tCO}_{2} \mathrm{e}\end{array}$ \\
\hline \multicolumn{4}{|c|}{ Crop measures } \\
\hline Fertilization standards & 2.9 & 380 & 550 \\
\hline Emission tax & 2.5 & -520 & -370 \\
\hline Nitrogen tax & 2.5 & -720 & -570 \\
\hline Irrigation modernization & 2.1 & -770 & -640 \\
\hline Water tax & 0.4 & -860 & -840 \\
\hline \multicolumn{4}{|c|}{ Livestock measures } \\
\hline $40 \%$ manure share & 1.3 & -70 & 10 \\
\hline $55 \%$ manure share & 2.7 & -250 & -80 \\
\hline Manure treatment plants & 1.4 & -250 & -170 \\
\hline \multicolumn{4}{|c|}{ Forest measures } \\
\hline Forest management & 7.0 & 140 & 560 \\
\hline
\end{tabular}

provide other additional environmental benefits to society, such as the abatement of nutrients leaching into water bodies, the reduction of ammonia emissions to the atmosphere, and improving biodiversity, among others. McLeod et al. (2015) indicate the importance of accounting for ancillary effects when evaluating GHG mitigation measures, and underline the lack of empirical estimations of such effects in the literature.

Table 6 presents the results of the sensitivity analysis of the social benefits of GHG mitigation with different estimates of the social cost of carbon. Results do not change when the social cost of carbon is reduced to $20 € / \mathrm{tCO}_{2} \mathrm{e}$, the mitigation potential remains equal to almost $10 \mathrm{MtCO}_{2} \mathrm{e}$ because of the low private cost of fertilization standards and forest management. However, the rise of carbon social cost to 80 $€ / \mathrm{tCO}_{2} \mathrm{e}$ increases the mitigation potential by $1.3 \mathrm{MtCO}_{2} \mathrm{e}$, to achieve more than 11 $\mathrm{MtCO}_{2} \mathrm{e}(31 \%$ of agricultural emissions). The measure that enters the policy mix is expanding the share of manure in crop fertilization to $40 \%$ because abatement benefits $\left(80 € / \mathrm{tCO}_{2} \mathrm{e}\right)$ would cover the manure application costs $\left(75 € / \mathrm{tCO}_{2} \mathrm{e}\right)$. All other measures entail very high social costs and would require much higher values of the social cost of carbon. 


\section{Conclusions and policy recommendations}

This paper provides a first estimate of the potential for mitigation in the whole Spanish agriculture, which we believe can be useful to guide policymakers in the design of country-level mitigation strategies. The paper collects fragmented information on GHG emissions and sinks and the cost-effectiveness of the most relevant mitigation measures in Spain. The results rank the selected measures by their costs and benefits, and show the most efficient mix of mitigation policy measures in agriculture. Results indicate that combining nitrogen standards with a carbon oriented forest management regime achieves an abatement close to $10 \mathrm{MtCO}_{2} \mathrm{e}$ and large social benefits. If the social cost of carbon is valued above $75 € / \mathrm{tCO}_{2} \mathrm{e}$, then the mitigation potential could further increase by expanding the application of manure in cultivation. Results indicate also that mitigation policies based on pure economic instruments, such as input taxes on nitrogen fertilizer or irrigation water, or emission taxes on $\mathrm{N}_{2} \mathrm{O}$, display high abatement costs for farmers and limited social benefits. The implication is that pure economic instruments can only be ancillary in the design of mitigation policies in agriculture. Investing in irrigation modernization is also a very costly mitigation measure.

This study could be extended to improve the accuracy of policy recommendations. A number of technical challenges remain in the estimation of costeffectiveness of measures. A first challenge is the inclusion of the transaction costs of measures, especially in the case of fertilization standards and substitution of synthetic fertilizers by manure, since both measures require adequate institutions for collective action. A second challenge is the spatial coverage of the optimization models simulating taxes, standards and irrigation modernization. The information used in this paper is derived from models that analyze agricultural activities of some regions of Spain, which are quite representative of Spanish farmland, and results are upscaled to country level. This study can be considered a sufficient approximation to the ordering of the cost-effectiveness of measures, although policy outcomes could be improved with a full country land use model. A third challenge is the inclusion of the effects of the interaction between different mitigation measures and the potential ancillary costs and benefits of mitigation measures. Lastly, it is important to understand why farmers 
are sometimes reluctant to adopt apparent win-win mitigation measures such as fertilization standards and forest management, and what incentives are needed to foster the adoption of those measures (McLeod et al. 2015).

As a final remark, agriculture in Spain holds a high potential to reduce GHG emissions (estimated at $28 \%$ of current agricultural emissions), and presents real opportunities for the reduction of GHG mitigation efforts in other sectors with higher abatement costs. However, the attainment of this potential faces a number of obstacles, such as high transaction costs, accommodation of stakeholders' strategic behavior, enforcement difficulties, forest land tenure, path dependency of current environmental regulation, and inertia of the political status quo. These shortcomings can be overcome by the introduction of good farming and forestry practices, strong technical assistance for farmers, improved monitoring and information systems, and the support of collective action through public incentives and institutions (Seitzinger et al., 2010).

\section{Acknowledgments}

Support for this research has been provided by the project INIA RTA2014-00050-00-00 from the Spanish Ministry of Economy and Competitiveness, partially financed with ERDF funds.

\section{References}

Albiac, J. (2009) Nutrient imbalances: Pollution remains. Science 326, 665.

Albiac, J., Kahil, M.T., Calvo, E., Crespo, D., Esteban, E., (2016) Evaluación SocioEconómica del Proyecto "LIFE-MANEV: Gestión y Tecnologías de Tratamiento de Estiércol para la Protección Medioambiental y la Sostenibilidad de la Ganadería en Europa, Documento de Trabajo 16/02, CITA, Zaragoza.

Albiac, J., Uche, J., Valero, A., Serra, L., Meyer, A., Tapia, J. (2003) The economic unsustainability of the Spanish National Hydrological Plan. International Journal of Water Resources Development 19, 437-458. 
Alvaro-Fuentes, J., del Prado, A., Yáñez-Ruiz, D.R. (2016) Greenhouse gas mitigation in the agricultural sector in Spain. Mitigation and Adaptation Strategies for Global Change 21, 969-973.

Bajzelj, B., Richards, K.S., Allwood, J.M., Smith, P., Dennis, J.S., Curmi, E., Gilligan, C.A. (2014) Importance of food-demand management for climate mitigation. Nature Climate Change 4, 924-929.

Bravo, F. (2007) El papel de los bosques españoles en la mitigación del cambio climático, Fundación Gas Natural, Barcelona.

Daudén, A., Quílez, D. (2004) Pig slurry versus mineral fertilization on corn yield and nitrate leaching in a Mediterranean irrigated environment. European Journal of Agronomy 21, 7-19.

Daudén, A., Teresa, M., Siegler, C. (2011) Proyecto demostrativo de gestión colectiva del purín en Aragón, Sociedad de Desarrollo Medioambiental de Aragón, Zaragoza.

De Cara, S., Houzé, M., Jayet, P.-A. (2005) Methane and Nitrous Oxide Emissions from Agriculture in the EU: A Spatial Assessment of Sources and Abatement Costs. Environmental and Resource Economics 32, 551-583.

Flotats, X., Foged, H., Blasi, A., Palatsi, J., Magri, A., Schelde, K., (2011) Manure processing technologies, Technical Report № II concerning Manure Processing Activities in Europe to the European Commission, Directorate-General Environment, Brussels.

Gernaat, D.E.H.J., Calvin, K., Lucas, P.L., Luderer, G., Otto, S.A.C., Rao, S., Strefler, J., van Vuuren, D.P. (2015) Understanding the contribution of non-carbon dioxide gases in deep mitigation scenarios. Global Environmental Change 33, 142-153.

Grosso, S.J.D., Cavigelli, M.A. (2012) Climate stabilization wedges revisited: can agricultural production and greenhouse-gas reduction goals be accomplished?. Frontiers in Ecology and the Environment 10, 571-578.

Herrero, M., Henderson, B., Havlik, P., Thornton, P.K., Conant, R.T., Smith, P., Wirsenius, S., Hristov, A.N., Gerber, P., Gill, M., Butterbach-Bahl, K., Valin, H., Garnett, T., Stehfest, E. (2016) Greenhouse gas mitigation potentials in the livestock sector. Nature Climate Change 6, 452-461.

IPCC, (2007) Climate Change 2007: Synthesis Report. Contribution of Working Groups I, II and III to the Fourth Assessment Report of the IPCC, IPCC, Geneva.

IPCC, (2014a) Climate Change 2014: Mitigation of Climate Change. Contribution of Working Group III to the Fifth Assessment Report of the Intergovernmental Panel on Climate Change, Cambridge University Press, Cambridge.

IPCC, (2014b) Summary for Policymakers, in: Field, C., Barros, V., Dokken, D. et al. (Eds.), Climate Change 2014: Impacts, Adaptation, and Vulnerability. Part A: Global and Sectoral Aspects. Contribution of Working Group II to the Fifth Assessment Report of the Intergovernmental Panel on Climate Change, Cambridge University Press, Cambridge. 
Kahil, M.T. (2011) Instrumentos de mitigación y adaptación al cambio climático en la agricultura de Aragón, Master thesis, Mediterranean Agronomic Institute of Zaragoza (IAMZ-CIHEAM), Zaragoza.

Kahil, M.T., Albiac, J. (2012) Instrumentos de política de cambio climático en la agricultura de Aragón. Revista Española de Estudios Agrosociales y Pesqueros 233, 15-44.

Kahil, M.T., Albiac, J. (2013) Greenhouse gases mitigation policies in the agriculture of Aragon, Spain. Bio-based and Applied Economics 2, 49-72.

Kahil, M.T., Dinar, A., Albiac, J. (2015a) Modeling water scarcity and droughts for policy adaptation to climate change in arid and semiarid regions. Journal of Hydrology 522, 95-109.

Kahil, M.T., Connor, J.D., Albiac, J. (2015b) Efficient water management policies for irrigation adaptation to climate change in Southern Europe. Ecological Economics 120, 226-233.

Kahil, M.T., Dinar, A., Albiac, J. (2016a) Cooperative water management and ecosystem protection under scarcity and drought in arid and semiarid regions. Water Resources and Economics 13, 60-74.

Kahil, M.T., Ward, F.A., Albiac, J., Eggleston, J., Sanz, D. (2016b) Hydro-economic modeling with aquifer-river interactions to guide sustainable basin management. Journal of Hydrology 539, 510-524.

Kahil, M.T., Albiac, J., Dinar, A., Calvo, E., Esteban, E., Avella, L., Garcia-Molla, M. (2016c) Improving the performance of water policies: Evidence from drought in Spain. Water 8 (34). doi:10.3390/w8020034.

Lecina, S., Isidoro, D., Playán, E., Aragüés, R. (2009) Efecto de la modernización de regadíos sobre la cantidad y la calidad de las aguas: la cuenca del Ebro como caso de estudio, Monografías INIA: Serie Agrícola 26, INIA, Madrid.

Leip, A., Achermann, B., Billen, G., Bleeker, A., Bouwman, A., de Vries, W., Dragosits, U., Doring, U., Fernall, D., Geupel, M., (2011) Integrating nitrogen fluxes at the European scale, in: Sutton, M., Howard, C., Erisman, J. et al. (Eds.), The European Nitrogen Assessment, Cambridge University Press, Cambridge.

MAGRAMA, (2014) Balance del Nitrógeno en la Agricultura Española 2012, MAGRAMA, Madrid.

MAGRAMA, (2015a) Anuario de Estadística 2014, MAGRAMA, Madrid.

MAGRAMA, (2015b) Encuesta sobre Superficies y Rendimientos de Cultivos (ESYRCE): Resultados Nacionales y Autonómicos, MAGRAMA, Madrid.

MAGRAMA, (2015c) Encuesta sobre Superficies y Rendimientos de Cultivos (ESYRCE). Informe sobre Regadíos en España, Subdirección General de Estadística, MAGRAMA, Madrid.

MAGRAMA, (2016) Inventario de emisiones de gases de efecto invernadero de España. Serie 1990-2014. Informe Resumen, Secretaría de Estado de Medio Ambiente, Dirección General de Calidad y Evaluación Ambiental, MAGRAMA, Madrid. 
Martínez, Y., Albiac, J. (2004) Agricultural pollution control under Spanish and European environmental policies. Water Resources Research 40, W105011W1050112.

Martínez, Y., Albiac, J. (2006) Nitrate pollution control under soil heterogeneity. Land Use Policy 23, 521-532.

MacLeod, M., Eory, V., Gruere, G., Lankoski, J. (2015) Cost-Effectiveness of greenhouse gas mitigation measures for agriculture: A literature review, OECD Food, Agriculture and Fisheries Papers, No. 89, OECD Publishing, Paris.

Montero, G., Ruiz-Peinado, R., Muñoz, M., (2005) Producción de biomasa y fijación de CO2 por los bosques españoles, Monografías INIA: Serie Forestal 13, INIA, Madrid.

Moran, D., Macleod, M., Wall, E., Eory, V., McVittie, A., Barnes, A., Rees, R., Topp, C.F.E., Moxey, A. (2011) Marginal Abatement Cost Curves for UK Agricultural Greenhouse Gas Emissions. Journal of Agricultural Economics 62, 93-118.

Notivol, E., (2008) Informe final del estudio sobre la funcionalidad de la vegetación leñosa de Aragón como sumidero de CO2, Gobierno de Aragón, Zaragoza.

Notivol, E., (2009) Fijación de Carbono por la Vegetación y Sumideros, Jornada sobre Bosques, Sumideros de Carbono y Cambio Climático, Gobierno de Aragón, Zaragoza.

Notivol, E., (2010) Sumideros naturales. El caso de Aragón, cambio climático, instrumentos normativos y de planificación nacional y autonómica, Gobierno de Aragón, Zaragoza.

Orus, F., Betran, J., Iguacel, F., Lopez, M., (2011) Fertilización con subproductos orgánicos: hacia una gestión sostenible de los nutrientes en la agricultura, Informaciones Técnicas, Gobierno de Aragón, Zaragoza.

Paustian, K., Lehmann, J., Ogle, S., Reay, D., Robertson, G.P., Smith, P. (2016) Climatesmart soils. Nature 532, 49-57.

Pearce, D., Atkinson, G., Mourato, S. (2006) Cost-Benefit Analysis and the Environment: Recent Developments, OECD, Paris.

Pérez Domínguez, I., Britz, W., Holm-Müller, K. (2009) Trading schemes for greenhouse gas emissions from European agriculture: A comparative analysis based on different implementation options. Review of Agricultural and Environmental Studies 90, 287-308.

Perni, A., Martínez-Paz, J.M. (2013) A participatory approach for selecting costeffective measures in the WFD context: The Mar Menor (SE Spain). Science of the Total Environment 458-460, 303-311.

Plaza-Bonilla, D., Alvaro-Fuentes, J., Arrúe, J.L., Cantero-Martínez, C. (2014) Tillage and nitrogen fertilization effects on nitrous oxide yield-scaled emissions in a rainfed Mediterranean area. Agriculture, Ecosystems \& Environment 189, 43-52.

Reisinger, A., Havlik, P., Riahi, K., van Vliet, O., Obersteiner, M., Herrero, M. (2013) Implications of alternative metrics for global mitigation costs and greenhouse gas emissions from agriculture. Climatic Change 117, 677-690. 
Richards, M., Bruun, T., Campbell, B.M., Huyer, S., Kuntze, V., Gregersen, L.E., Madsen, S.T.N., Oldvig, M.B., Vasileiou, I., (2015) How countries plan to address agricultural adaptation and mitigation: An analysis of Intended Nationally Determined Contributions, CCAFS Info Note, Copenhagen.

Sanchez, B., Iglesias, A., McVittie, A., Alvaro-Fuentes, J., Ingram, J., Mills, J., Lesschen, J.P., Kuikman, P.J. (2016) Management of agricultural soils for greenhouse gas mitigation: Learning from a case study in NE Spain. Journal of Environmental Management 170, 37-49.

Seitzinger, S.P., Mayorga, E., Bouwman, A.F., Kroeze, C., Beusen, A.H.W., Billen, G., Van Drecht, G., Dumont, E., Fekete, B.M., Garnier, J., Harrison, J.A. (2010) Global river nutrient export: A scenario analysis of past and future trends. Global Biogeochemical Cycles 24, n/a-n/a.

Smith, P., Bustamante, M., Ahammad, H., al., e., (2014) Agriculture, Forestry and Other Land Use (AFOLU), in: Edenhofer, O., Pichs-Madruga, R., Sokona, Y. et al., (Eds.), Climate Change 2014: Mitigation of Climate Change. Contribution of Working Group III to the Fifth Assessment Report of the Intergovernmental Panel on Climate Change, Cambridge University Press, Cambridge.

Smith, P., Martino, D., Cai, Z., Gwary, D., Janzen, H., Kumar, P., McCarl, B., Ogle, S., O’Mara, F., Rice, C., Scholes, B., Sirotenko, O., Howden, M., McAllister, T., Pan, G., Romanenkov, V., Schneider, U., Towprayoon, S. (2007) Policy and technological constraints to implementation of greenhouse gas mitigation options in agriculture. Agriculture. Ecosystems \& Environment 118, 6-28.

Smith, S., Braathen, N., (2015) Monetary carbon values in policy appraisal: An overview of current practices and key issues, Environment Working Paper No. 92, OECD, Paris.

Teresa, M., E., Herrero, B., Bescós (2016). Evaluación de sistemas de gestión de estiércol en Europa. Resultados del Proyecto LIFE-MANEV, Sociedad Aragonesa de Gestión Ambiental, Zaragoza.

UNFCCC, (2015) Adoption of the Paris Agreement, UNFCCC, Paris.

Wollenberg, E., Richards, M., Smith, P., Havlík, P., Obersteiner, M., Tubiello, F.N., Herold, M., Gerber, P., Carter, S., Reisinger, A., van Vuuren, D.P., Dickie, A., Neufeldt, H., Sander, B.O., Wassmann, R., Sommer, R., Amonette, J.E., Falcucci, A., Herrero, M., Opio, C., Roman-Cuesta, R.M., Stehfest, E., Westhoek, H., OrtizMonasterio, I., Sapkota, T., Rufino, M.C., Thornton, P.K., Verchot, L., West, P.C., Soussana, J.-F., Baedeker, T., Sadler, M., Vermeulen, S., Campbell, B.M. (2016) Reducing emissions from agriculture to meet the $2{ }^{\circ} \mathrm{C}$ target. Global Change Biology 22(12), 3859-3864. 